\title{
PENENTUAN FAKTOR PENGELOLAAN TAMBAK YANG MEMPENGARUHI PRODUKTIVITAS TAMBAK KABUPATEN MAMUJU, PROVINSI SULAWESI BARAT

\author{
DETERMINING OF BRACKISHWATER POND MANAGEMENT FACTORS THAT \\ EFFECT ON THE BRACKISHWATER POND PRODUCTIVITY IN MAMUJU REGENCY, \\ WEST SULAWESI PROVINCE
}

\author{
Akhmad Mustafa, Erna Ratnawati dan Irmawati Sapo \\ Balai Riset Perikanan Budidaya Air Payau \\ Jalan Makmur Daeng Sitakka No. 129 Maros 90512, Sulawesi Selatan \\ Telp. (0411) 371544
}

\begin{abstract}
One of regency in West Sulawesi Province that has vast area of brackishwater ponds is Mamuju Regency. However, there is not yet information on pond management that conducted by farmers in Mamuju Regency. Hence, it was carried out a research that aim to know pond management factors that effect on the pond productivity in Mamuju Regency. Survey method that applied to find primary data and ponds production also pond management by means of questionnaires. The dependent variable in this research was total production, while the independent variables were pond management factors that consists of 30 variables. Multiple regressions with dummy variable were used to analyze the data in predicting total production. The results show that total production of brackishwater ponds in Mamuju Regency is $349.5 \mathrm{~kg} / \mathrm{ha} / \mathrm{season}$ in average. There are seven pond management variables that effect on total production in Mamuju Regency i.e. stocking density of milkfish, stocking density of tiger prawn, out-break disease, initial liming, duration of milkfish culture, initial pest control with teaseed and size of tiger prawn that stocked in the brackihswater pond. The total productivity of brackishwater pond can be increase through increasing dosage of initial liming, increasing duration of milkfish culture, increasing dosage of teaseed as initial pest control as well as increasing size of tiger prawn that stocked in the brackishwater ponds.
\end{abstract}

Keywords : brackishwater pond, management, productivity, Mamuju Regency

\section{Pendahuluan \\ Jenis perikanan budidaya yang}

dilakukan di Indonesia meliputi budidaya laut, budidaya tambak, budidaya kolam dan budidaya sawah. Di antara berbagai jenis perikanan budidaya tersebut, produksi tertinggi yaitu 559.612 ton $(38,10 \%$ dari total produksi perikanan budidaya) berasal dari budidaya tambak dengan luas mencapai 489.811 ha (luas kotor) pada tahun 2004 (Anonim, 2006). Usaha perikanan budidaya tambak merupakan kegiatan yang memanfaatkan kawasan pesisir yang mampu memberikan kontribusi cukup besar terhadap pendapatan masyarakat pesisir, penyedia lapangan kerja, dan perolehan devisa negara yang potensial. Provinsi Sulawesi Barat adalah provinsi terbaru di Indonesia yang merupakan pemekaran dari Provinsi Sulawesi Selatan. Dari informasi data yang ada (Anonim, 2003) menunjukkan bahwa di Sulawesi Barat terdapat budidaya tambak seluas 6.985 ha, budidaya air tawar di kolam seluas 302 ha dan di sawah seluas 625 ha. Provinsi Sulawesi Barat terdiri dari enam kabupaten yaitu: Kabupaten
Polewali Mandar, Mamasa, Majene, Mamuju dan Mamuju Utara. Di Kabupaten Polewali Mandar seluruh potensi budidaya tambak telah termanfaatkan (Anonim, 2004b) dan potensi budidaya laut sekitar 2.000 ha (Basuni, 1990) atau sekitar 2.470 ha (Anonim, 2004a), di Kabupaten Majene terdapat potensi budidaya tambak seluas 750 ha (Talle, 1990) dan di Kabupaten Mamuju dan Mamuju Utara terdapat potensi budidaya tambak sekitar 22.950 ha (Sukarman, 1990).

Pengelolaan tambak yang dilakukan oleh pembudidaya tambak sangat bervariasi. Pemupukan dan pengapuran serta ketersediaan air dan adanya saluran memberikan pengaruh yang nyata terhadap produktivitas tambak di Kabupaten Maros, Takalar dan Bulukumba, Provinsi Sulawesi Selatan (Hanafi, 1990). Pengelolaan budidaya yang dilakukan oleh pembudidaya di tambak Kabupaten Pinrang telah diteliti oleh Mustafa dan Ratnawati (2007), di Kabupaten Bulukumba oleh Ratnawati et al. (2009) dan Kabupaten Lampung Selatan oleh Ratnawati et al. (2009). 
Mengetahui faktor pengelolaan yang berpengaruh terhadap produktivitas tambak diharapkan dapat menjadi bahan pertimbangan dalam upaya peningkatan produktivitas tambak. Pengelolaan tambak merupakan faktor penting setelah penentuan kesesuaian lahan budidaya tambak dalam rangka pengembangan ilmu pengetahuan dan budidaya tambak berkelanjutan (Karthik et al., 2005). Identifikasi dari peubah faktor pengelolaan tambak yang tidak mempengaruhi produktivitas tambak perlu diketahui supaya dapat diikuti oleh pembudidaya untuk mengefektifkan biaya produksi tanpa mempengaruhi produktivitas tambak. Oleh karena itu dilakukan penelitian yang bertujuan untuk mengetahui faktor-faktor dominan pengelolaan tambak yang berpengaruh terhadap produktivitas tambak Kabupaten Mamuju, Provinsi Sulawesi Barat.

\section{Materi dan Metode Penelitian}

Penelitian dilaksanakan di kawasan pertambakan yang tersebar di 11 kecamatan di Kabupaten Mamuju, Provinsi Sulawesi Barat (Gambar 1). Untuk mendapatkan informasi awal mengenai kegiatan budidaya tambak di Kabupaten Mamuju, maka dilakukan pertemuan dengan staf Dinas Kelautan dan Perikanan Kabupaten Mamuju di Mamuju. Tambak terpilih ditentukan secara acak dari Peta Mapping Unit (Satuan Pemetaan) yaitu gabungan Peta Landscape (Bentuk Lahan) dan Land Use (Penggunaan Lahan). Pembudidaya tambak dari tambak terpilih menjadi responden dalam penelitian ini. Titik-titik pengamatan ditentukan posisinya dengan Global Positioning System (GPS). Peta yang menunjukkan titik-titik pengamatan dibuat dengan bantuan teknologi Penginderaan Jauh (Inderaja) dan Sistem Informasi Geografis (SIG). Citra satelit yang digunakan adalah Landsat-7 ETM.

Metode penelitian yang diaplikasikan adalah metode survei, termasuk untuk mendapatkan data primer dari produksi dan pengelolaan tambak yang dilakukan melalui pengajuan kuisioner kepada responden secara terstruktur (Wirartha, 2006). Sebagai peubah tergantung atau peubah tidak bebas atau peubah respon dalam penelitian ini adalah produksi total tambak. Produksi total tambak merupakan total produksi udang windu (Penaeus monodon) dan ikan bandeng (Chanos chanos) (Hanafi, 1990), sebab tambak yang terpilih semuanya melakukan budidaya secara polikultur antara udang windu dan ikan bandeng. Peubah bebas atau peubah prediktor adalah pengelolaan tambak yang terdiri atas 30 peubah. Sebagai peubah boneka dalam penelitian ini adalah: perlakuan remediasi terhadap tanah dasar tambak, waktu penebaran benih, sistem pergantian air dan serangan penyakit.

Statistik deskriptif digunakan untuk

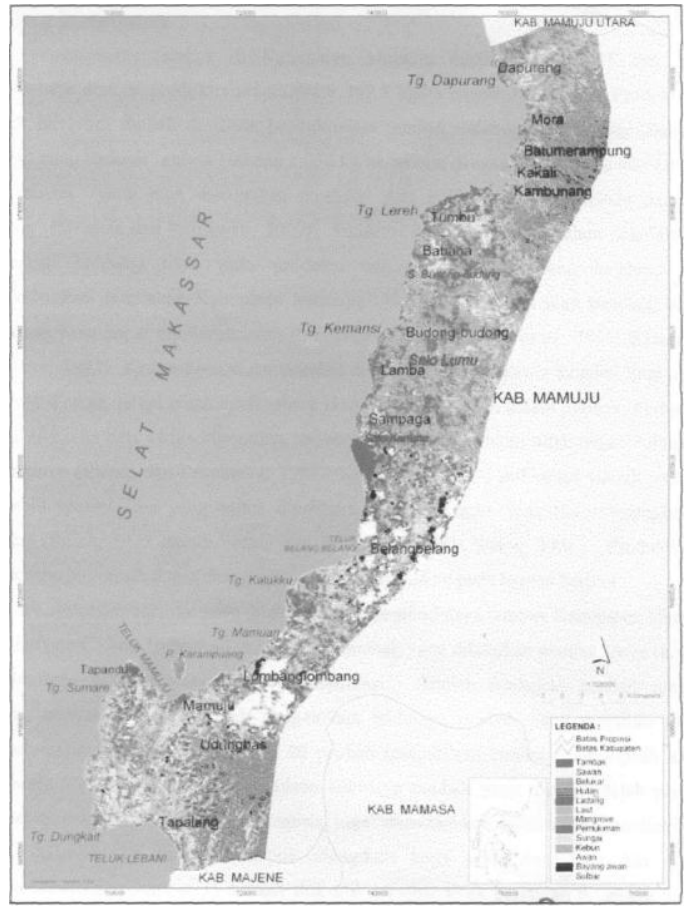

Gambar 1. Lokasi penelitian di Kabupaten Mamuju, Provinsi Sulawesi Barat 
mengetahui gambaran umum (minimum, maksimum, rata-rata, standar deviasi) dari data yang ada. Matriks korelasi digunakan untuk mengetahui adanya gejala multikolinearitas. Grafik plot PP (Probabilitas harapan dan Probabilitas pengamatan) digunakan untuk menguji kenormalan distribusi data. Scatterplot regresi digunakan untuk mengetahui adanya gejala heteroskedastisitas. Uji DW (DurbinWatson) digunakan untuk mendeteksi adanya gejala autokorelasi. Dalam memilih persamaan regresi ganda 'terbaik' maka digunakan metode langkah mundur (backward) (Draper dan Smith, 1981). Analisis regresi berganda untuk mengetahui peubah bebas yang mempengaruhi peubah tidak bebas di bidang perikanan telah diaplikasikan antara lain oleh Nessa (1985), Meagaung et al. (2000), Mustafa dan Ratnawati
(2005), Ratnawati et al. (2008), Halachmi et al. (2005) dan Patadjai (2007).

Uji $\mathrm{R}^{2}$ yang disesuaikan (adjusted $R^{2}$ ) digunakan untuk mengetahui besarnya peubah bebas menjelaskan peubah tidak bebas. Uji $F$ atau analisis ragam digunakan untuk menguji signifikansi model regresi. Model persamaan regresi berganda yang diuji adalah (Sokal dan Rohlf, 1981; Tabachnick dan Fidell, 1996):

$\mathrm{Y}=\mathrm{a}+\mathrm{b}_{1} \mathrm{X}_{1}+\mathrm{b}_{2} \mathrm{X}_{2}+\ldots+\mathrm{b}_{\mathrm{n}} \mathrm{X}_{\mathrm{n}}$ (Persamaan 1)

dimana:

$$
\begin{array}{lll}
\mathrm{Y} & \text { produksi total tambak } \\
\mathrm{a} & =\text { koefisien konstanta } \\
\mathrm{b}_{1}, \mathrm{~b}_{2} \ldots \mathrm{b}_{\mathrm{n}}= & \text { koensien regres' } \\
\mathrm{X}_{1}, \mathrm{X}_{2}, \ldots \mathrm{X}_{\mathrm{n}}= & \text { peubah bebas yaitu } \\
& \text { pengelolaan tambak. }
\end{array}
$$

Tabel 1. Statistik deskriptif semua peubah yang diamati dalam penentuan peubah pengelolaan tambak yang berpengaruh terhadap produktivitas tambak di Kabupaten Mamuju. Provinsi Sulawesi Barat

\begin{tabular}{|l|c|c|c|c|c|}
\hline \multicolumn{1}{|c|}{ Peubah } & Minimum & Maksimum & Kisaran & Rata-rata & $\begin{array}{c}\text { Standar } \\
\text { deviasi }\end{array}$ \\
& & & & & \\
\hline Produksi total (kg/ha/siklus) & 15,0 & 1625,0 & 1610,0 & 349,5 & 304,92 \\
Remediasi & & & & & \\
Lama pengeringan (hari) & 0,0 & 1,0 & 1,0 & 0,3 & 0,46 \\
Dosis saponin (ppm) & 2,0 & 90,0 & 88,0 & 12,7 & 16,01 \\
Dosis Brestan (ppm) & 0,00 & 55,56 & 55,56 & 10,26 & 16,155 \\
Dosis kapur (kg/ha) & 0,00 & 7.50 & 7,50 & 0,52 & 1,544 \\
Dosis urea (kg/ha) & 0,00 & 400,00 & 400,0 & 57,72 & 114,633 \\
Dosis TSP/SP-36 (kg/ha) & 0.00 & 625,00 & 625,0 & 109,12 & 107,932 \\
Ukuran udang windu (PL) & 0,00 & 625,00 & 625,0 & 69,75 & 112,476 \\
Ukuran ikan bandeng (hari) & 11,0 & 20,0 & 9,0 & 14,7 & 3.14 \\
Lama pengangkutan (jam) & 3,0 & 60,0 & 57,0 & 10,2 & 9.51 \\
Waktu penebaran) & 0,08 & 15,0 & 14,92 & 3,34 & 3,992 \\
Padat penebaran udang & 1,0 & 4,0 & 3.0 & 1,7 & 1.21 \\
(ekor/ha) & 1000,0 & 50000,0 & 49000,0 & 10072,7 & 9245,15 \\
Padat penebaran ikan & & & & & \\
bandeng (ekor/ha) & 500.0 & 15000,0 & 14500,0 & 2889,3 & 2493,05 \\
Tinggi air (cm) & & & & & \\
Pergantian air (\%) & 20,0 & 120,0 & 100,0 & 56,9 & 27,30 \\
Frekuensi pergantian air & 10,0 & 60,0 & 50,0 & 35,7 & 11,42 \\
Sistem pergantian airc) & 2,0 & 30,0 & 28,0 & 13,2 & 6,06 \\
Lama pemeliharaan udang & 1,0 & 2,0 & 1,0 & 1,3 & 0,47 \\
windu (hari) & 60,0 & 210,0 & 150,0 & 120,0 & 27,55 \\
Lama pemeliharaan ikan & 75,0 & 240,0 & 165,0 & 146,5 & 35,17 \\
bandeng (hari) & & & & & \\
Serangan penyakit ${ }^{\text {d) }}$ & 0.0 & 1,0 & 1.0 & 0,9 & 0,33 \\
\hline
\end{tabular}

a) $0=$ Tidak; $1=$ Ya

b) 1 = Pagi; 2 = Siang; 3 = Sore; 4 = Pagi dan sore

c) $1=$ Gravitasi; $2=$ Pompa

d) $0=$ Tidak; $1=$ Ya 
Seluruh data dianalisis dengan bantuan Program Statistical Product and Service Solution (SPSS) versi 15,0 (SPSS, 2006; Coakes et al., 2008).

\section{Hasil dan Pembahasan}

Produktivitas tambak di Kabupaten Mamuju berkisar antara 15 dan 1.625 $\mathrm{kg} / \mathrm{ha} /$ musim dengan produktivitas rata-rata $349,5 \mathrm{~kg} / \mathrm{ha} / \mathrm{musim}$ (Tabel 1). Produktivitas tambak ini lebih rendah daripada produktivitas tambak Kabupaten Pinrang (Sulawesi Selatan) yang berkisar antara 100 dan 3.050 $\mathrm{kg} / \mathrm{ha} /$ musim dengan produktivas rata-rata 499 $\mathrm{kg} / \mathrm{ha} /$ musim yang juga merupakan produksi dari polikultur udang windu dan ikan bandeng (Mustafa dan Ratnawati, 2007). Produksi yang dilaporkan dalam penelitian ini merupakan produksi total yaitu produksi udang windu dan ikan bandeng yang dipolikulturkan di tambak Kabupaten Mamuju. Udang windu dan ikan bandeng adalah komoditas yang dapat dipolikulturkan di tambak (Ranoemihardjo et al., 1979; Eldani dan Primavera, 1981). Kedua komoditas tersebut secara umum menuntut kondisi lingkungan yang relatif sama, tetapi menempati relung ekologi yang berbeda dalam tambak. Perbedaan habitat makanan dari kedua komoditas tersebut yang menyebabkan tidak terjadi kompetisi di antaranya (Eldani dan Primavera, 1981). Konsep dasar dari polikultur adalah jika dua atau lebih spesies ikan yang cocok dipelihara secara bersama-sama akan meningkatkan produksi (Reich, 1975 dalam Eldani dan Primavera, 1981; Shang, 1986). Produktivitas tambak tersebut masih dapat ditingkatkan seperti dijelaskan pada bagian berikut.

Pengelolaan tambak yang dilakukan oleh pembudidaya tambak Kabupaten Mamuju relatif beragam. Ada 30 peubah pengelolaan tambak yang dilakukan pembudidaya tambak di Kabupaten Mamuju yang telah diidentifikasi. Setelah dilakukan analisis matriks korelasi, temyata banyak peubah pengelolaan budidaya tambak yang memiliki gejala multikolinearitas, sehingga hanya ada 20 peubah pengelolaan tambak yang dipilih untuk analisis lebih lanjut. Peubah pengelolaan budidaya tambak yang dipilih adalah peubah yang lebih mudah diukur. Hasil analisis juga menunjukkan bahwa data berdistribusi normal (Gambar 2) dimana titiktitik mengikuti haris linier dan tidak ada gejala heteroskedastisitas (Gambar 3) dimana titik-titik tersebar tidak beraturan di sekitar 0 dari sumbu y.

Pada Tabel 2 terlihat bahwa $\mathrm{R}^{2}$ yang disesuaikan (adjusted $R^{2}$ ) tertinggi $(0,804)$ dan standar galat estimasi (standard error of estimate) terendah $(134,881)$ didapatkan pada Model 14. Dalam hal ini Model 14 lebih baik dalam menjelaskan peubah bebas memprediksi peubah tidak bebas. Selain itu, karena standar galat estimasi lebih kecil dari standar deviasi produksi tambak yang besarnya 304,92 $\mathrm{kg} / \mathrm{ha} /$ musim (Tabel 2), maka model regresi lebih baik dalam bertindak sebagai prediktor produksi total tambak daripada rata-rata produksi tambak itu sendiri. Selanjutnya dari hasil analisis ragam (Tabel 3) menunjukkan Model 14 dapat digunakan untuk memprediksi produksi tambak di Kabupaten Mamuju ( $P=$ 0,000).

Telah disebutkan sebelumnya bahwa $\mathrm{R}^{2}$ yang disesuaikan tertinggi adalah 0,804 . Hal ini berarti bahwa $80,4 \%$ produksi total tambak dapat dijelaskan oleh peubah pengelolaan tambak yang meliputi: padat penebaran ikan bandeng, padat penebaran udang windu, terjadinya serangan penyakit, pengapuran awal, lama pemeliharaan ikan bandeng, pemberantasan hama awal dengan saponin dan ukuran benur windu yang ditebar, sedangkan sisanya $(19,6 \%)$ dijelaskan oleh faktor lain yang tidak diamati dalam penelitian ini.

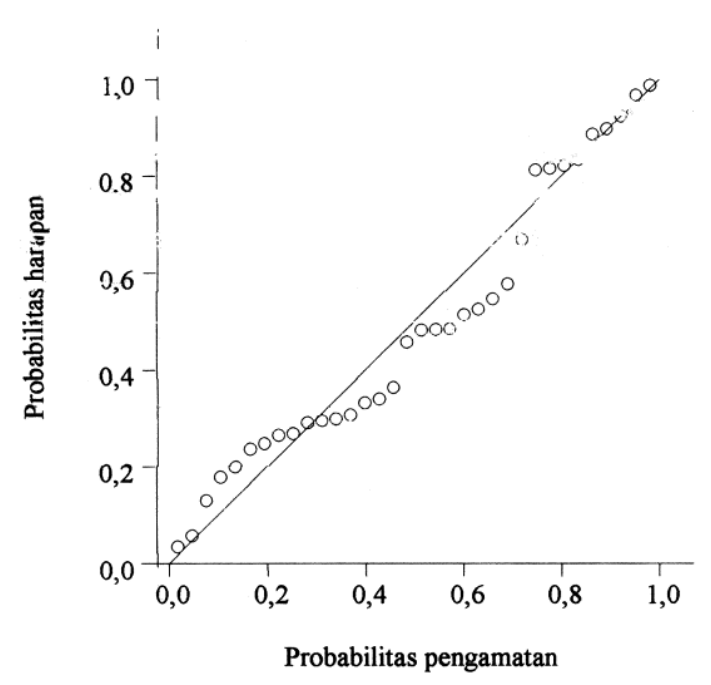

Gambar 2.Grafik PP (Probabilitas harapan dan Probabilitas pengamatan) normal dari standar regresi sisa untuk menguji kenormalan distribusi data 


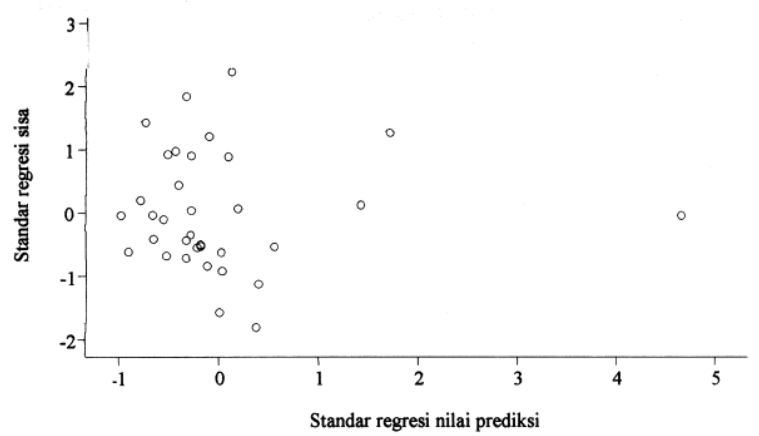

Gambar 3. Grafik pencar regresi untuk mengetahui adanya gejala heteroskedastisitas

Hasil analisis lebih lanjut didapatkan nilai koefisien konstanta dan koefisien regresi dari persamaan regresi (Tabel 4) yang terpilih dan selanjutnya digunakan untuk memprediksi produksi total tambak di Kabupaten Mamuju. Peubah pengelolaan tambak yang berperan dalam menentukan produktivitas tambak di Kabupaten Mamuju digambarkan dalam persamaan regresi sebagai berikut:

$$
\begin{aligned}
\mathrm{Y}= & 189,003+0.057 \mathrm{X}_{1}+0,014 \mathrm{X}_{2}- \\
& 237,781 \mathrm{X}_{3}+0,603 \mathrm{X}_{4}+1,744 \mathrm{X}_{5}+ \\
& 2,243 \mathrm{X}_{6}+12,612 \mathrm{X}_{7}
\end{aligned}
$$

(Persamaan 2)

$$
\begin{aligned}
& \text { dimana : } \\
& \mathrm{Y}= \text { produksi total }(\mathrm{kg} / \mathrm{ha} / \text { musim }) \\
& \mathrm{X}_{1}= \text { padat penebaran ikan bandeng } \\
&(\text { ekor } / \text { ha } / \text { musim })(P=0,001) \\
& \mathrm{X}_{2}= \text { padat penebaran udang windu } \\
&(\text { ekor } / \text { ha/musim })(P=0,003) \\
& \mathrm{X}_{3}= \text { serangan penyakit }(P=0,004) \\
& \mathrm{X}_{4}= \text { pengapuran awal }(\mathrm{kg} / \mathrm{ha} / \mathrm{musim}) \\
&(P=0,030) \\
& \mathrm{X}_{5}= \text { lama pemeliharaan ikan bandeng } \\
& \text { (hari) }(P=0,044) \\
& \mathrm{X}_{6}= \text { pemberantasan hama awal dengan } \\
& \text { saponin }(\mathrm{ppm})(P=0,180) \\
& \mathrm{X}_{7}= \text { ukuran udang windu yang ditebar } \\
&(\mathrm{PL})(P=0,183)
\end{aligned}
$$

Dari 20 peubah faktor pengelolaan tambak yang dikaji dalam penelitian ini temyata hanya 7 peubah yaitu: padat penebaran ikan bandeng, padat penebaran udang windu, serangan penyakit, pengapuran awal, lama pemeliharaan ikan bandeng, pemberantasan hama awal dengan saponin dan ukuran udang windu yang ditebar (Persamaan 2) yang merupakan peubah pengelolaan budidaya yang berpengaruh secara nyata dalam menentukan produktivitas tambak di Kabupaten Mamuju.
Tiga belas peubah pengelolaan tambak lainnya yaitu: remediasi terhadap tanah dasar, lama pengeringan, dosis Brestan, dosis urea, dosis TSP/SP-36, ukuran ikan bandeng, lama pengangkutan benih, waktu penebaran benih, tinggi air dalam tambak, persentase pergantian air, frekuensi pergantian air, sistem pergantian air dan lama pemeliharaan udang windu yang dilakukan oleh pembudidaya tambak di Kabupaten Mamuju tidak memberikan pengaruh terhadap produksi total tambak.

Dari Persamaan 2 terlihat bahwa koefisien konstanta sebesar 189,003 yang berarti produktivitas tambak dapat diprediksi mencapai $189,003 \mathrm{~kg} / \mathrm{ha} /$ musim kalau tidak ada kontribusi dari peubah pengelolaan tambak. Hal ini menunjukkan bahwa peubah pengelolaan tambak yang meliputi: padat penebaran ikan bandeng, padat penebaran udang windu, serangan penyakit, pengapuran awal, lama pemeliharaan ikan bandeng, pemberantasan hama awal dengan saponin dan ukuran udang windu yang ditebar berpengaruh besar terhadap produktivitas tambak di Kabupaten Mamuju.

Dari Persamaan 2 terlihat bahwa koefisien regresi dari padat penebaran ikan bandeng adalah $+0,057$ yang berarti bahwa penambahan padat penebaran ikan bandeng 1 ekor/ha/musim dapat meningkatkan (tanda +) produktivitas tambak di Kabupaten Mamuju sebesar $0,057 \mathrm{~kg} / \mathrm{ha} / \mathrm{musim}$. Dengan penambahan 1 ekor/ha/musim dan hanya meningkatkan produksi $57 \mathrm{~g} / \mathrm{ha} /$ musim, maka secara ekonomis tidak menguntungkan. Secara umum, ikan bandeng yang dipelihara selama 147 hari dapat mencapai berat lebih dari 300 g/ekor. Hal ini diduga karena rata-rata padat penebaran ikan bandeng yang ditebar sudah cukup tinggi yaitu 2.889 ekor/ha/musim yang dipolikulturkan dengan udang windu dengan padat penebaran 10.073 ekor/ha/musim. Hal yang sama juga terjadi pada udang windu, walaupun peningkatan padat penebaran 1 ekor/ha/musim dapat meningkatkan 0,014 $\mathrm{kg} / \mathrm{ha} / \mathrm{musim}$, tetapi ini juga tergolong tidak ekonomis. Hal ini juga disebabkan oleh padat penebaran udang windu yang juga tergolong tinggi apabila dipolikultur dengan ikan bandeng. Di Kabupaten Lampung Selatan, Provinsi Lampung, pembudidaya tambak hanya menebar 9.910 ekor udang windu yang dipolikulturkan dengan 1.409 ekor ikan bandeng/ha/musim (Ratnawati et al., 2009). Produksi tertinggi dari udang windu dan ikan bandeng diperoleh pada padat penebaran udang windu dan ikan bandeng berturut-turut 8.000 dan 2.000 ekor/ha yang dipolikultur selama 4 bulan tanpa pemberian pakan buatan (Eldani dan Primavera, 1981). 
Padat penebaran udang windu dan ikan bandeng yang diaplikasikan oleh pembudidaya tambak di Kabupaten Pinrang adalah rata-rata 29.995 dan 2.062 ekor/ha/musim yang disertai dengan pemberian pakan buatan (Mustafa dan Ernawati, 2008).

Serangan penyakit di tambak Kabupaten Mamuju secara nyata dapat menurunkan produksi. Hal yang sama juga telah dilaporkan oleh Ratnawati et al. (2009) di Kabupaten Bulukumba yang bahkan ada tambak tanpa berproduksi sebagai akibat serangan penyakit pada monokultur udang windu. Tiga jenis penyakit yang menyerang udang windu di tambak Kabupaten Mamuju adalah penyakit yang disebabkan oleh White Spot Syndrome Virus (WSSV), Insang Merah dan Bintik Merah. Infeksi WSSV pada udang windu merupakan masalah besar dalam industri udang global, terutama di Asia Tenggara (Rajendran et al., 1999) dan merupakan penyakit yang umum mempengaruhi produksi udang windu (Flegel et al., 1996).

Dari Persamaan 2 terlihat juga bahwa penambahan dosis kapur awal dapat juga meningkatkan produktivitas tambak di Kabupaten Mamuju. Dari Tabel 1 terlihat bahwa rata-rata pembudidaya tambak di Kabupaten Mamuju hanya mengaplikasikan kapur awal dengan dosis 57,72 kg/ha/musim dan bahkan ada yang tidak mengaplikasikan kapur sama sekali. Dari hasil pengamatan di lapangan yang ditunjukkan dengan indikator biologis dan indikator tanah, menunjukkan bahwa tanah tambak di Kabupaten Mamuju tergolong tanah sulfat masam. Tanah sulfat masam adalah nama umum yang diberikan kepada tanah atau sedimen yang mengandung bahan sulfidik atau pint (FeS2). Pirit merupakan hasil persenyawaan antara besi yang merupakan penyusun mineral liat silikat dalam bahan induk tanah dengan sulfat yang berasal dari air laut. Pint dalam kondisi alami yaitu dalam keadaan anaerob tidak menimbulkan masalah bagi organisme. Ketika tanah sulfat masam yang mengandung pirit terekspos atau teroksidasi, misalnya digali untuk dijadikan tambak, akan menyebabkan terjadinya penurunan $\mathrm{pH}$ tanah, peningkatan kelarutan unsur atau senyawa beracun dan pengikatan unsur hara makro sehingga berdampak pada produktivitas tambak yang sangat rendah dan bahkan tidak berproduksi sama sekali (Mustafa dan Rachmansyah, 2008). Dalam hal ini, dosis kapur yang diaplikasikan oleh pembudidaya tambak untuk tanah sulfat masam tergolong sangat rendah, oleh karena itu, peningkatan dosis kapur dapat meningkatkan produktivitas tambak di Kabupaten Mamuju. Dengan pengapuran dapat memperbaiki kualitas tanah berupa peningkatan $\mathrm{pH}$ dan penurunan unsur toksik.

Walaupun ikan bandeng dipelihara lebih lama daripada udang windu di tambak Kabupaten Mamuju (147 hari vs 120 hari), akan tetapi penambahan lama pemeliharaan ikan bandeng masih dapat meningkatkan produktivitas tambak di Kabupaten Mamuju. Dari Persamaan 2 terlihat bahwa penambahan 1 hari pemeliharaan ikan bandeng dapat meningkatkan produktivitas tambak 1,744 $\mathrm{kg} / \mathrm{ha} /$ musim. Penambahan masa pemeliharaan berimplikasi pada penambahan berat ikan bandeng, sehingga juga terjadi peningkatan produksi.

Rata-rata pembudidaya tambak di Kabupaten Mamuju hanya mengaplikasikan saponin dengan dosis $10 \mathrm{ppm}$ (Tabel 1). Biji tanaman teh mengandung $10-15 \%$ saponin yang efektif dalam mematikan hama ikan yang tidak diinginkan, namun tidak mematikan udang. Di tambak Kabupaten Pesawaran, Provinsi Lampung, para pembudidaya udang vaname (Litopenaeus vannamei) mengaplikasikan saponin dengan dosis 20 ppm pada salinitas tambak lebih rendah dari 20 ppt dan saponin dengan dosis 15 ppm pada salinitas lebih besar 20 ppt (Mustafa et al., 2009). Oleh karena itu, peningkatan dosis saponin dalam pemberantasan hama awal secara nyata berpengaruh terhadap peningkatan produktivitas tambak di Kabupaten Mamuju. Menurut Primavera (1993) dan Shariff et al. (2000), saponin tidak hanya mematikan hama ikan yang tidak diinginkan, tetapi juga dapat merangsang pergantian kulit dalam budidaya udang. Saponin dosis 2-3 ppm selama 24 jam diaplikasikan untuk merangsang pergantian kulit pada udang windu dan saponin dosis 20-30 ppm direkomendasikan untuk pembasmian penyakit bintik hitam (blackspot disease) pada udang (Shariff et al., 2000). Saponin dosis 5-25 ppm telah digunakan dalam pembasmian infeksi protozoa di tambak (Baticados dan Paclibare, 1992). Saponin dapat juga berfungsi sebagai pupuk organik yang dapat merangsang pertumbuhan alga di tambak (Lia.oetal.,2000).

Permintaan pembudidaya tambak akan benur pada musim kekurangan benur memaksa pengusaha hatchery untuk melepaskan pascalarva yang masih kecil (pascalarva 8-12). Pengusaha hatchery pun pada saat benur melimpah biasanya melepaskan pascalarva 1218 yang juga dianggap pascalarva yang masih kecil. Pascalarva 8-18 masih dianggap terlalu kecil untuk ditebar di tambak, karena sulit 
dalam penghitungannya secara cepat dan tepat. Sintasan yang rendah sering dialami oleh pembudidaya tambak ketika menggunakan benur berukuran pascalarva 8-18. Perubahan kondisi lingkungan, tampaknya menimbulkan stres yang menyebabkan kematian tinggi pada pascalarva berukuran kecil itu. Dari informasi yang ada menunjukkan bahwa pembudidaya tambak yang menebar benur ukuran pascalarva 8-18 ke petak pembesaran maka kematian dapat mencapai $70 \%$. Oleh karena itu peningkatan ukuran benur yang ditebar berdampak pada peningkatan produksi tambak. Dengan menebar ukuran benur yang lebih besar, memungkinkan benur dapat lebih tahan terhadap perubahan lingkungan dan dapat menghindar dari pemangsaan. Dengan menggunakan benih ukuran yang lebih besar, pendugaan sintasan untuk penentuan jumlah pakan lebih akurat sehingga pemborosan pakan dapat dikurangi yang tercermin pada rendahnya rasio konversi pakan (Mustafa dan Mangampa, 1990; Mangampa et al., 1990, 1994; Mustafa et al., 2009; Mangampa dan Mustafa, 1992). Selain itu, dampak negatif kelebihan pakan yang dapat menyebabkan penurunan kualitas lingkungan pertambakan juga dapat diminimalkan. Peningkatan pascalarva (PL) udang windu 1 hari yang ditebar di tambak dapat meningkatkan produktivitas tambak $12,612 \mathrm{~kg} / \mathrm{ha} /$ musim di Kabupaten Mamuju.

\section{Kesimpulan}

Rata-rata produksi total tambak Kabupaten Mamuju, Provinsi Sulawesi Barat sebesar 349,5 kg/ha/musim yang merupakan produksi total dari udang windu yang dipolikulturkan dengan ikan bandeng. Ada tujuh peubah pengelolaan tambak yaitu: padat penebaran ikan bandeng, padat penebaran udang windu, ada tidaknya serangan penyakit, pengapuran awal, lama pemeliharaan ikan bandeng, pemberantasan hama awal dengan saponin dan ukuran udang windu yang ditebar yang mempengaruhi produktivitas tambak di Kabupaten Mamuju. Hal ini menunjukkan bahwa produksi total tambak masih dapat ditingkatkan melalui pengelolaan tambak yang meliputi peningkatan dosis kapur awal, peningkatan lama pemeliharaan ikan bandeng, peningkatan dosis saponin sebagai pemberantasan hama awal serta peningkatan ukuran benur windu yang ditebar.

\section{Daftar Pustaka}

Anonim. 1990. Potensi sumberdava perikanan pantai Selat Makassar. Dalam: Cholik, F., M.J.R. Yakob, Rosmiati, A. Mustafa, H.
Pramana dan A.M. Pirzan (eds.). Presiding Temu Karya Ilmiah Potensi Sumberdaya Perikanan Pantai Sulawesi Selatan. Baia. Penelitian Budidaya Pantai, Maros. him. 121-124.

Anonim. 2003. Laporan Statistik Perikanan Sulawesi Selatan 2002. Dinas Perikanan dan Kelautan Propinsi Sulawesi Selatan, Makassar.

Anonim. 2004a. Laporan Pelaksanaan Pembangunan Sektor Perikanan dan Kelautan Periode 2000-2004 (5 Tahun). Dinas Perikanan dan Kelautan Kabupaten Mamuju, Mamuju.

Anonim. 2004b. Peluang Usaha dan Investasi pada Sektor Kelautan dan Perikanan di Kabupaten Polewali Mamasa Propinsi Sulawesi Barat. Dinas Kelautan dan Perikanan Kabupaten Polewali Mamasa, Polewali.

Basuni, I. 1990. Potensi sumberdaya perikanan pantai Kabupaten Polmas. Dalam: Cholik, F., Yakob, M.J.R. Yakob, Rosmiati, A. Mustafa, H. Pramana dan A.M. Pirzan (eds.). Presiding Temu Karya Ilmiah Potensi Sumberdaya Perikanan Pantai Sulawesi Selatan. Balai Penelitian Budidaya Pantai, Maros. him. 81-94.

Baticados, M.C.L. and J.O. Paclibare. 1992. The use of chemotherapeutic agents in aquaculture in the Philippines. In: Shariff, M., R.P. Subasinghe and J.R. Arthur (eds.). Diseases in Asian Aquaculture I. Fish Health Section, Asian Fisheries Society, Manila, p. 531-546.

Coakes, S.J-, L. Steed and J. Price. 2008. SPSS: Analysis without Anguish: Version 15.0 for Windows. John Wiley \& Sons Australia, Ltd., Milton, Qld. 270 pp.

Draper, N.R. and H. Smith. 1981. Applied Regression Analysis. Second Edition. John Wiley \& Sons, New York. 709 pp.

Eldani, A. and J.H. Primavera. 1981. Effect of different stocking combination of growth, production and survival rate of milkfish (Chanos chanos Forskal) and prawn (Penaeus monodon Fabricius) in polyculture in brackishwater ponds. Aquaculture 23: 59-72.

Flegel, T.W. 1996. A turning point for sustainable aquaculture: the white spot virus crisis in Asia shrimp culture. Aquaculture Asia 1: 29-34.

Halachmi, I., Y. Simon, R. Guette and E.M. Hallerman. 2005. A novel computer simulation model for design and management of re-circulating aquaculture systems. AquaculturalEngineering 32: 
443-464.

Hanafi, A. 1990. Socio-economic and managerial profiles of brackishwater aquaculture in South Sulawesi. Jurnal Perikanan Budidaya Pantai 6(2): 97-114.

Karthik, M., J. Suri, N. Saharan and R.S. Biradar. 2005. Brackish water aquaculture site selection in Palghar Taluk, Thane district of Maharashtra, India, using the techniques of remote sensing and geographical information system. Aquacultural Engineering 32: 285-302.

Liao, I.C., J.-J. Guo and M.-S. Su. 2000. The use of chemicals in aquaculture in Taiwan, Province of China. In: Arthur, J.R., C.R. Lavilla-Pitogo and R.P. Subasinghe (eds.). Use of Chemicals in Aquaculture in Asia. Southeast Asian Fisheries Development Center Aquaculture Department, Tigbauan, Iloilo, Philippines, p.193-205.

Mangampa, M dan A. Mustafa. 1992. Budidaya udang windu, Penaeus monodon pada padat penebaran berbeda dengan menggunakan benih yang dibantut. Jurnal Penelitian Budidaya Pantai 8(4): 37-48.

Mangampa, M., A. Mustafa dan A.G. Mangawe. 1990. Penelitian pendahuluan pada budidaya tambak sistem semi-intensif dengan menggunakan benur windu, Penaeus monodon yang dibantut. Jurnal Penelitian Budidaya Pantai 6(1): 40-46.

Mangampa, M., N. Kabangnga, A. Mustafa, dan M. Tjaronge. 1994. Budidaya udang windu, Penaeus monodon secara intensif menggunakan benur yang dibantut dalam wadah yang berbeda. Jurnal Penelitian Budidaya Pantai 10(5): 89-95.

Meagaung, W.M., M.N. Nessa, A. Hanafi dan M.N. Jalaluddin. 2000. Faktor-faktor dominan yang berpengaruh terhadap akumulasi bahan organik pada tambak udang intensif. Lingkungan \& Pembangunan 20(1); 43-51.

Mustafa, A. dan E. Ratnawati. 2005. Faktor pengelolaan yang berpengaruh terhadap produksi rumput laut (Gracilaria verrucosd) di tambak tanah sulfat masam (Studi kasus di Kabupaten Luwu, Propinsi Sulawesi Selatan). Jurnal Penelitian Perikanan Indonesia II(7): 67-77.

Mustafa, A. dan E. Ratnawati. 2007. Faktorfaktor dominan yang mempengaruhi produktivitas tambak di Kabupaten Pinrang, Sulawesi Selatan. Jurnal Riset Akuakultur 2(1): 117-133.

Mustafa, A., I. Sapo dan M. Paena. 2009. Studi penggunaan produk kimia dan biologi pada budidaya udang vaname
(Litopenaeus vannamei) di tambak Kabupaten Pesawaran, Provinsi Lampung. Balai Riset Perikanan Budidaya Air Payau, Maros. 28 him, Mustafa, A. dan M. Mangampa. 1990. Usaha budidaya udang tambak menggunakan benur windu, Penaeus monodon yang berbeda lama pembantutannya. Jurnal Penelitian Budidaya Pantai 6(2): 35-48.

Mustafa, A. dan Rachmansyah. 2008. Kebijakan dalam pemanfaatan tanah sulfat masam untuk budidaya tambak. Dalam: Sudradjat, A., I W. Rusastra dan S. Budiharsono (eds.), Analisis Kebijakan Pembangunan Perikanan Budidaya. Pusat Riset Perikanan Budidaya, Jakarta, him. 1-11.

Nessa, M.N. 1985. Pengaruh Faktor Pengelolaan dan Lingkungan terhadap Daya Hasil Tambak (Kasus Kabupaten Pangkep, Sulawesi Selatan). Disertasi S3. Fakultas Pascasarjana, Institut Pertanian Bogor, Bogor. 213 him.

Patadjai, R.S. 2007. Pertumbuhan, Produksi dan Kualitas Rumput Laut Kappaphycus alvarezii (Doty) Doty padaBerbagai Habitat Budidaya yang Berbeda. Disertasi S3. Program Pascasarjana, Universitas Hasanuddin, Makassar. 163 him.

Primavera, J.H. 1993. A critical review of shrimp pond culture in the Philippines. Rev. Fish. Sci. 1: 151-201.

Rajendran, K.V., K.K. Vijayan, T.C. Santiago and R.M. Krol. 1999. Experimental host range and histopathology of white spot syndrome virus (WSSV) infection in shrimp, prawns, crabs and lobsters from India. Journal of Fish Diseases 22: 183191.

Ratnawati, E., A. Mustafa dan Rachmansyah. 2008. Faktor status pembudidaya, kondisi dan pengelolaan tambak yang berpengaruh terhadap produksi rumput laut (Gracilaria verrucosd) di tambak tanah sulfat masam Kabupaten Luwu Utara Provinsi Sulawesi Selatan. Jurnal Riset Akuakultur 3(2): 275287.

Ratnawati, E., Mustafa, A. dan Utojo. 2009. Faktor pengelolaan yang mempengaruhi produksi udang windu di tambak Kabupaten Bulukumba, Provinsi Sulawesi Selatan. Dalam: Presiding Seminar Nasional Perikanan 2009: Teknologi Penangkapan Ikan, Permesinan Perikanan, Teknologi Pengolahan Hasil Perikanan, Sosial Ekonomi Perikanan. Pusat Penelitian dan Pengabdian Masyarakat, Sekolah Tinggi Perikanan, Jakarta, him. 617-626. 
Sokal, R.R. and F.J. Rohlf. 1981. Biometry: The Principles and Practice of Statistics in Biological Research. Second edition: W.H. Freeman and Co., New York. 859 pp. SPSS (Statistical Product and Service Solution). 2006. SPSS 15.0 BriefGuide. SPSS Inc., Chicago. 217pp.

Sukarman. 1990. Potensi sumberdaya perikanan pantai Kabupaten Mamuju. Dalam: Cholik, F., M.J.R. Yakob, Rosmiati, A. Mustafa, H. Pramana dan A.M. Pirzan (eds.). Presiding Temu Karya Ilmiah Potensi Sumberdaya Perikanan Pantai Sulawesi Selatan. Balai Penelitian Budidaya Pantai, Maros. him. 99-104.
Tabachnick, B.G. and L.S. Fidell. 1996. Using Multivariate Statistics. Third edition. Harper Collins College Publishers, New York. 880 pp.

Talle, U. 1990. Potensi sumberdaya perikanan pantai Kabupaten Majene. Dalam Cholik, F., M.J.R. Yakob, Rosmiati, A. Mustafa, H. Pramana dan A.M. Pirzan (eds.). Presiding Temu Karya Ilmiah Potensi Sumberdaya Perikanan Pantai Sulawesi Selatan. Balai Penelitian Budidaya Pantai, Maros. him. 95-98.

Wirartha, I M. 2006. Metodologi Penelitian Sosial Ekonomi. Penerbit Andi, Yogyakarta. $383 \mathrm{hlm}$. 